\title{
Breastfeeding knowledge and relation to prevalence ${ }^{*}$
}

\author{
Conhecimentos sobre aleitamento e a relação com a sua prevalência \\ Conocimientos sobre lactancia y relación con su prevalencia
}

How to cite this article:

Suárez-Cotelo MDC, Movilla-Fernández MJ, Pita-García P, Fernández Arias B, Novío S. Breastfeeding knowledge and relation to prevalence. Rev Esc Enferm USP. 2019;53:e03433. DOI: http://dx.doi.org/10.1590/S1980-220X2018004503433

\section{María del Carmen Suárez-Cotelo ${ }^{1,2}$ \\ María Jesús Movilla-Fernández ${ }^{3,2}$ \\ D Paula Pita-García ${ }^{4}$ \\ Betty Fernández Arias ${ }^{1}$ \\ Silvia Novío ${ }^{5}$}

* Extracted from the disssertation "Estudio de la construcción que hacen las madres del soporte recibido para la instauración y mantenimiento de la lactancia materna", Universidad de la Coruña, 2017.

${ }^{1}$ Hospital Provincial de Pontevedra, Pontevedra, Spain.

${ }^{2}$ Universidad de la Coruña, Grupo de Investigación Cardiovascular (GRINCAR), Spain.

${ }^{3}$ Universidad de la Coruña, Facultad de Enfermería y Podología, Campus de Esteiro, Ferrol, Coruña, Spain.

${ }^{4}$ Hospital Arquitecto MarcideNóvoa Santos, Departamento de Obstetrícia, Ferrol, Coruña, Spain.

${ }^{5}$ Universidad de Santiago de Compostela, Facultad de Enfermería, Departamento de Psiquiatría, Radiología, Salud Pública,

Enfermería y Medicina, Santiago de

Compostela, Coruña, Spain.

\section{ABSTRACT}

Objective: Determine the level of knowledge about maternal breastfeeding and analyze to what extent this influences the intention to breastfeed after the introduction of infant feeding at the 6th and 16th weeks and at 6 months postpartum. Method: Prospective descriptive study conducted with pregnant women in Galicia (Spain). By means of a self-filling questionnaire, data were collected on the intention of the woman to feed the newborn and their knowledge about breastfeeding. Pregnant women were also contacted at the 6th and 16th weeks and at 6 months postpartum to know the type of feeding they gave their child. Results: 297 pregnant women participated in the study, of which $90.4 \%$ wanted to exclusively breastfeed their baby, however, only $28.2 \%$ continued up to 6 months. The level of knowledge about breastfeeding was regular and it was observed that it influences both the intention and the type of feeding of the newborn, thus it is an element to be considered when developing educational strategies aimed at increasing breastfeeding rates. Conclusion: The level of pregnant women's knowledge about breastfeeding is regular and influences the choice of how to feed their babies and the duration of exclusive breastfeeding. Strategies should be implemented to increase knowledge and improve breastfeeding rates.

\section{DESCRIPTORS}

Breast Feeding; Knowledge; Pregnancy; Maternal-Child Nursing; Health Education.
Corresponding author:

María del Carmen Suárez-Cotelo

Department of Obstetrics, Hospital

Provincial de Pontevedra, Loureiro

Crespo, 2, Pontevedra, Spain.

msuarezcotelo@gmail.com
Received: 02/26/2018

Approved: 08/15/2018 


\section{INTRODUCTION}

Breastfeeding $(\mathrm{BF})$ is the ideal food source for the newborn (NB), besides providing numerous benefits to the mother and society ${ }^{(1-4)}$. The World Health Organization (WHO) recommends exclusive breastfeeding (EBF) up to 6 months and, only afterwards, the introduction of complementary feeding while maintaining BF up to 2 years or older ${ }^{(5)}$. However, many countries do not follow these recommendations. Specifically, in Brazil, the prevalence of EBF decreases dramatically over time and varies greatly according to the zones (between $27 \%$ and $56 \%$, according to the latest national survey ${ }^{(6)}$, and the same occurs in Spain ${ }^{(7)}$.

Numerous factors have been positively and negatively related to the start and duration of $\mathrm{BF}^{(8)}$. Especially those associated with the social and cultural environment are highlighted, as $\mathrm{BF}$ is not an instinctive behavior ${ }^{(9)}$. Thus, it has recently been suggested that the level of competence of women on the topic could lead to differences in the exclusivity and duration of $\mathrm{BF}^{(10-11)}$. Establishing the level of knowledge about breastfeeding would also be interesting in order to outline intervention strategies to promote $\mathrm{EBF}$ in the NB.

The aim of this study is to determine the level of knowledge of pregnant women about $\mathrm{BF}$ and to analyze to what extent this influences the intention to breastfeed after the introduction of infant feeding at the 6th and 16th weeks and at 6 months postpartum.

\section{METHOD}

\section{TYPE OF STUDY}

A descriptive, prospective study was conducted between June 2014 and July 2015.

\section{SCENARIO}

Ferrol health district, one of the 13 Health districts in Galicia. This District consists of 22 Health Centers, which serve people of different socio-economic levels, and 16 of these Centers have midwives. The follow-up of pregnancy in these centers is representative of that carried out in Galicia, an Autonomous Community in Spain. In seven of these centers, midwives voluntarily agreed to cooperate with the study.

\section{Population}

The sample consisted of 297 pregnant women in the third trimester of pregnancy that attended maternal education (ME) classes with the midwife at their health center during the data collection period.

Women aged 18 and over, gestating a single fetus, able to read and write in Spanish, and who understood the study instructions were invited to participate in the study.

The exclusion criteria were women whose pregnancy ended in fetal death, who would thus not have follow-up in the postpartum period or with a medical contraindication that would seriously hinder BF.

The sample size was calculated according to the average of pregnancies in the area in the 5 years prior to the start of the study, which was 1,175 deliveries/year. Based on these data, and in order to obtain a statistical significance of $95 \%$, with an accuracy of $3 \%$, an expected proportion of $5 \%$ and approximately $15 \%$ of losses, the sample size of the study was defined as 204 women.

\section{Data Collection}

All women who met the selection criteria were selected on the day they went to ME classes. Those interested in participating received an envelope from the lead investigator with the following documentation: study information sheet with instructions to complete the questionnaires; informed consent; socio-demographic data sheet; and basic BF knowledge questionnaire.

Women interested in participating volunteered to provide a form of contact used to collect information about the feeding of the baby during the postpartum period (Figure 1).

Three data collection tools were used:

\section{Knowledge Questionnaire about BF}

The basic BF knowledge questionnaire was prepared and validated by Ferro Sosa and Flores Condory ${ }^{(12)}$, who submitted it for evaluation by experts (seven health professionals) and also carried out a pilot test.

This questionnaire, consisting of a total of 22 questions, obtained a Cronbach Alpha result of 0.72 , which indicates a reliable result ${ }^{(13)}$.

To determine the level of $\mathrm{BF}$ knowledge, each question in the questionnaire was evaluated and, depending on the number of correct answers, classified as follows:

Poor level of knowledge: score of less than 9.5.

Regular level of knowledge: score of between 9.5 and 11.5. Good level of knowledge: score greater than 11.5.

In order to estimate the completion time for the questionnaire, the adequacy of the writing, any difficulties in understanding and whether the questions were adapted to the variables that they were intended to analyze, a pilot study was conducted. With the participation of 18 women, this study required the introduction of non-substantial modifications to adapt the questionnaire to the scope and objectives of the present study.

The "BF knowledge" variable was grouped into: good/ regular and poor level of knowledge, to calculate its relationship with postpartum results.

\section{SOCIO-DEMOGRAPHIC DATASHEET}

Socio-demographic information was structured in 11 questions that referred to age, marital status, level of studies, number of births, occupation, nationality, place of residence and the health center attending the pregnancy. It also asked about previous experience in BF (in cases of multi-parity) and what they thought about feeding their future baby in the first 6 months - with EBF, artificial breastfeeding (AF) or mixed breastfeeding (Mixed F). The variables "previous $\mathrm{BF}$ experience" and "future feeding intent" were grouped, except for the sample description, into: $\mathrm{EBF}$ and $\mathrm{AF} /$ mixed $\mathrm{F}$. 
RECORD SHEET OF THE TYPE OF FEEDING GIVEN TO THE NB AT THE 6TH AND 16TH WEEKS AND AT 6 MONTHS POSTPARTUM。

The variables used were as follows:

- EBF: The infant receives only breast milk. Does not ingest any other food or drink. May receive drops, syrups or oral rehydration salts.

- $A F$ : The infant receives artificial milk solely or together with other solid or semi-solid foods.

- Mixed F: The infant receives breast milk and can ingest any food or liquid, including artificial milk.

For data analysis, the variable "type of postpartum feeding" was grouped into two: EBF and AF/mixed F.

\section{ANALYSIS AND PROCESSING OF DATA}

Statistical analysis was carried out using IBM SPSS, Version 20.0 (SPSS for Windows, SPSS Inc., Madrid,
Spain). The values of $\mathrm{p}<0.05$ were considered statistically significant.

Records with more than $50 \%$ of blank variables were eliminated from the analysis $(n=2)$. In the remaining records, lost values were estimated using a regression method.

Descriptive statistics and contingency tables were used to represent the characteristics of the sample, using the chisquare test to: i) analyze the relationship between basic BF knowledge and socio-demographic factors; ii) study the relationship between basic BF knowledge and the NB feeding intention; iii) determining the relationship between basic BF knowledge and the type of feeding at week 6 , week 16 , and 6 months; iv) determine the relationship between the woman's intention to feed the baby and the type of feeding at week 6 and 16 and 6 months postpartum.

Bivariate logistic regression was used to determine the relationship between socio-demographic factors and BF knowledge.

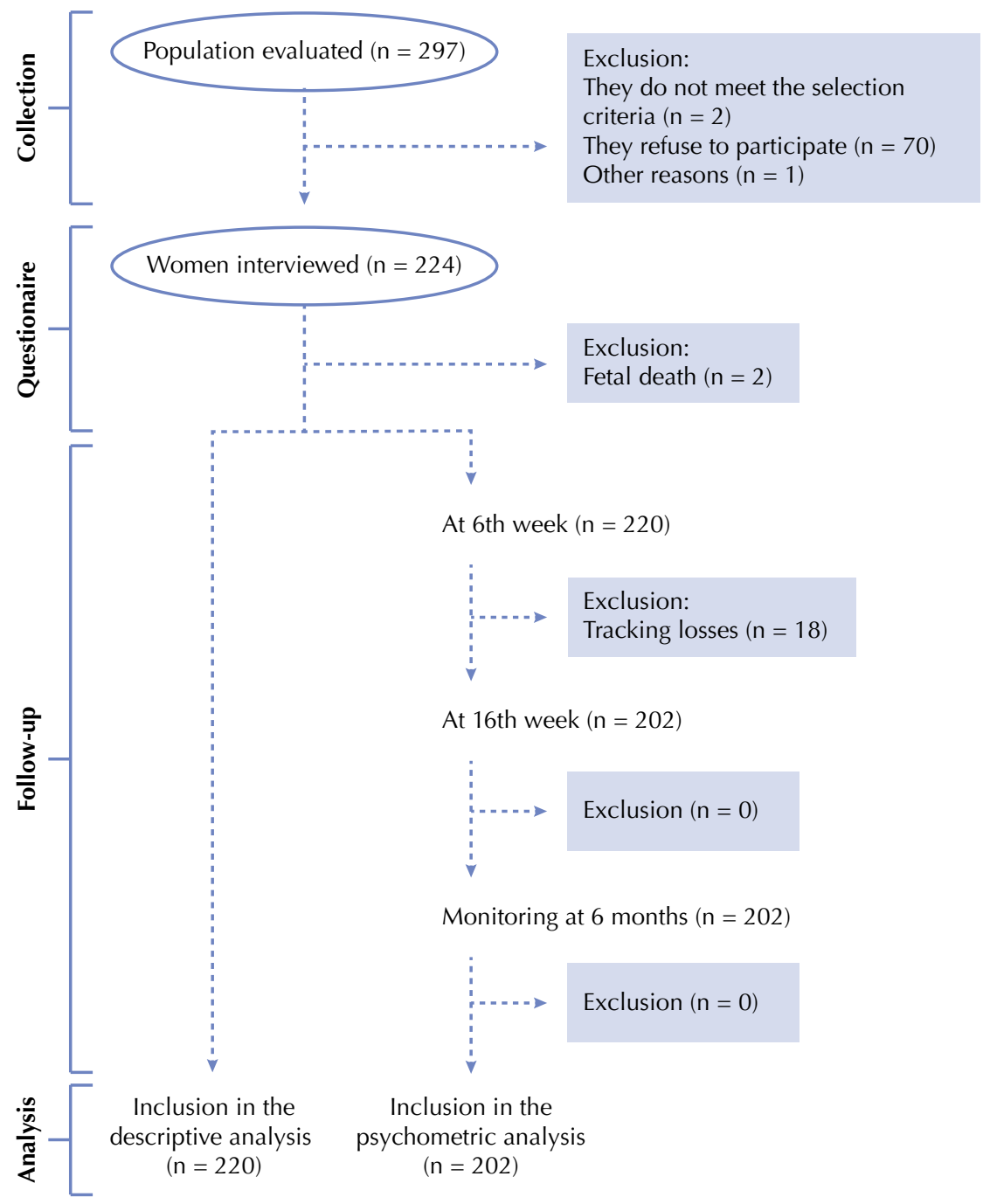

Figure 1 - Scheme of participants in the study. 


\section{ETHICAL ASPECTS}

The collection of the sample began after obtaining the approval of the Galician Investigation Ethical Committee (registration number: 2014/064) and the signing of the Informed Consent Form (ICF) by the participants involved.

\section{RESULTS}

\section{SAMPLE DESCRIPTION}

Most of the participants were of Spanish nationality, married, aged between 18 and 34, had completed higher education and had paid work. Considering that only $22.3 \%$ of the women were multiparous, it should be noted that of these, $89.8 \%$ had previously breastfed, exclusively or partially (Table 1).

The vast majority of women (90.4\%) wanted to feed their baby up to 6 months with EBF and when asked during the third trimester of pregnancy, only $9.6 \%$ wanted to do so with $\mathrm{AF}$ or mixed $\mathrm{F}$.

The prevalence of EBF decreased over time $(63.9 \%$ in the 6th week; $52 \%$ in the 16 th week; and $28.2 \%$ at 6 months). The type of feeding and the mother's intention in the prenatal phase were statistically related. These differences are observed both at the 6th and 16th week and at 6 months after childbirth. Most women who intended to feed their babies with EBF did so.
According to the $\mathrm{BF}$ knowledge questionnaire, most women's level of BF knowledge was regular (55.5\%). Only $25 \%$ had a good level of knowledge, and $19.5 \%$ had a poor level. The aspects in which women had less knowledge were: the recommendation to breastfeed the baby exclusively until 6 months of age; the preservation of breast milk; the management of diarrhea; and the correct breastfeeding posture (Table 3).

Socio-demographic factors that can influence women's BF knowledge are age, level of studies and parity. Specifically, older, multiparous and women with higher studies obtained higher scores in the knowledge questionnaire $(\mathrm{p}<0.05)$.

The woman's BF knowledge was related to her intention to breastfeed her baby. Those that thought of feeding their babies with $\mathrm{AF}$ or mixed $\mathrm{F}$ had less $\mathrm{BF}$ knowledge (9.5\% good knowledge level) than those who planned to feed their babies with EBF (26.4\% good knowledge level) ( $\mathrm{p}=0.01)$.

Women who fed their babies with EBF had a higher level of BF knowledge than those who fed them with AF or mixed $\mathrm{F}$ in the 16th week postpartum, the limit of statistical significance being at 6 months postpartum (Table 4).

When bivariate logistic regression was performed considering breastfeeding knowledge as a dependent variable, the results showed that the level of knowledge was not influenced by age $(p=0.122)$, marital status $(p=0.633)$, level of studies $(p=0.572)$, number of births $(p=0.618)$ or occupation $(p=0.148)$.

Table 1 - Characteristics of the study population and level of BF knowledge - Galicia, Spain, 2014-2015.

\begin{tabular}{|c|c|c|c|c|c|c|c|c|}
\hline \multicolumn{9}{|c|}{ Level of BF knowledge $(n=220)$} \\
\hline \multirow{2}{*}{\multicolumn{2}{|c|}{ Characteristics of the study population }} & \multicolumn{2}{|c|}{ Good } & \multicolumn{2}{|c|}{ Regular } & \multicolumn{2}{|c|}{ Poor } & \multirow{2}{*}{$\mathbf{p}$} \\
\hline & & $\mathbf{n}$ & $\%$ & $\mathbf{n}$ & $\%$ & $\mathbf{n}$ & $\%$ & \\
\hline \multirow{2}{*}{ Maternal age } & $18-34$ years old & 27 & 19.9 & 77 & 56.6 & 32 & 23.5 & \multirow{2}{*}{0.02} \\
\hline & $\geq 35$ years & 28 & 33.7 & 45 & 54.2 & 10 & 12 & \\
\hline \multirow{3}{*}{ Marital status } & Married & 36 & 28.8 & 67 & 53.6 & 22 & 17.6 & \multirow{3}{*}{0.32} \\
\hline & Cohabiting & 16 & 19 & 52 & 61.9 & 16 & 19 & \\
\hline & Single & 3 & 33.3 & 3 & 33.3 & 3 & 33.3 & \\
\hline \multirow{2}{*}{ Nationality } & Spanish & 54 & 25.4 & 117 & 54.9 & 42 & 19.7 & \multirow{2}{*}{0.68} \\
\hline & Other & 1 & 14.3 & 5 & 71.4 & 1 & 14.3 & \\
\hline \multirow{3}{*}{ Level of studies } & Secondary or lower & 10 & 13.5 & 47 & 63.5 & 17 & 23.0 & \multirow{3}{*}{0.01} \\
\hline & Vocational training & 10 & 20.8 & 28 & 58.3 & 10 & 20.8 & \\
\hline & Complete/incomplete higher education & 35 & 36.5 & 47 & 49.0 & 14 & 14.6 & \\
\hline \multirow{2}{*}{ Parity } & Primiparous & 36 & 21.1 & 100 & 58.5 & 35 & 20.5 & \multirow{2}{*}{0.04} \\
\hline & Multiparous & 19 & 38.8 & 22 & 44.9 & 8 & 16.3 & \\
\hline \multirow{3}{*}{ Occupation } & Paid work & 37 & 23.4 & 92 & 58.2 & 29 & 18.4 & \multirow{3}{*}{0.05} \\
\hline & Student & 0 & 0.0 & 3 & 42.9 & 4 & 57.1 & \\
\hline & Domestic & 18 & 33.3 & 27 & 50.0 & 9 & 16.7 & \\
\hline \multirow{2}{*}{$\begin{array}{c}\text { Previous breastfeeding } \\
\text { experience* }^{*}\end{array}$} & Exclusive breastfeeding & 13 & 43.3 & 13 & 43.3 & 4 & 13.3 & \multirow{2}{*}{0.64} \\
\hline & Artificial/mixed feeding & 6 & 31.6 & 9 & 47.4 & 4 & 21.1 & \\
\hline
\end{tabular}

* Calculated among multiparous women. 
Table 2 - Relationship between future feeding intent and postpartum outcome - Galicia, Spain, 2014-2015.

\begin{tabular}{|c|c|c|c|c|c|c|}
\hline & & \multicolumn{4}{|c|}{ Future feeding intent } & \multirow{3}{*}{$p$} \\
\hline \multicolumn{2}{|c|}{ Baby feeding type } & \multicolumn{2}{|c|}{ EBF } & \multicolumn{2}{|c|}{ AF/mixed F } & \\
\hline & & $\mathbf{n}$ & $\%$ & $\mathbf{n}$ & $\%$ & \\
\hline \multirow{2}{*}{$6 w$} & EBF & 124 & 62.9 & 4 & 19 & \multirow{2}{*}{0.00} \\
\hline & AF/mixed F & 57 & 28.9 & 16 & 76.2 & \\
\hline \multirow{2}{*}{$16 w$} & EBF & 100 & 50.8 & 4 & 19 & \multirow{2}{*}{0.00} \\
\hline & AF/mixed F & 81 & 41.1 & 16 & 76.2 & \\
\hline \multirow{2}{*}{$6 \mathrm{~m}$} & EBF & 56 & 28.4 & 1 & 4.8 & \multirow{2}{*}{0.02} \\
\hline & AF/mixed F & 125 & 63.5 & 19 & 90.5 & \\
\hline
\end{tabular}

Note: AF: artificial feeding; EBF: exclusive breastfeeding; Mixed F: mixed breastfeeding; m: months; w: weeks.

Table 3 - Basic knowledge questionnaire - Galicia, Spain, 2014-2015.

\begin{tabular}{|c|c|c|c|}
\hline Question & Answer & $N(\mathbf{2 2 0})$ & $\%$ \\
\hline \multirow{3}{*}{$\begin{array}{l}\text { Do you know what } \\
\text { breastfeeding is? }\end{array}$} & Yes & 215 & 98.2 \\
\hline & No & 4 & 1.8 \\
\hline & No response & 1 & 0.5 \\
\hline \multirow{4}{*}{$\begin{array}{l}\text { During the first } 6 \text { months } \\
\text { of life of the baby he/she } \\
\text { should be fed with: }\end{array}$} & Breast milk plus aniseed tea & 3 & 1.4 \\
\hline & Breast milk only & 210 & 95.9 \\
\hline & Breast milk plus artificial milk & 5 & 2.3 \\
\hline & No response & 2 & 1 \\
\hline \multirow{5}{*}{$\begin{array}{l}\text { Up to what age should } \\
\text { you breastfeed the baby } \\
\text { exclusively? }\end{array}$} & Up to 2 years & 134 & 61.2 \\
\hline & Up to 6 months & 58 & 26.5 \\
\hline & Up to 12 months & 26 & 11.9 \\
\hline & There is no age limit & 1 & 0.5 \\
\hline & No response & 1 & 0.5 \\
\hline \multirow{5}{*}{$\begin{array}{l}\text { When should you start } \\
\text { breastfeeding the baby? }\end{array}$} & 4 hours after birth & 6 & 2.8 \\
\hline & Immediately after birth & 198 & 93 \\
\hline & 24 hours after birth & 1 & 0.5 \\
\hline & The first time the baby cries hungrily & 8 & 3.8 \\
\hline & No response & 7 & 3.2 \\
\hline \multirow{4}{*}{$\begin{array}{l}\text { How often should the } \\
\text { baby be breastfed? }\end{array}$} & Every 2 hours & 20 & 9.3 \\
\hline & Each time the child cries or there is demand & 193 & 89.8 \\
\hline & Every 6 hours & 1 & 0.5 \\
\hline & No response & 6 & 2.8 \\
\hline \multirow{4}{*}{$\begin{array}{l}\text { Your baby cries from } \\
\text { hunger or thirst during } \\
\text { the day and night. } \\
\text { What would you do? }\end{array}$} & Administer artificial milk. & 5 & 2.3 \\
\hline & Breastfeed only & 203 & 94.4 \\
\hline & Administer breast milk and tea & 6 & 2.8 \\
\hline & No response & 6 & 2.8 \\
\hline \multirow{4}{*}{$\begin{array}{l}\text { If you are working or out } \\
\text { of the house. How should } \\
\text { you feed your baby? }\end{array}$} & I'd have to give him/her artificial milk. & 4 & 1.9 \\
\hline & I'd breastfeed when I'm with the baby and feed with artificial milk when I'm separated from him/her. & 8 & 3.7 \\
\hline & I would preferably administer breast milk extracted at home or at work & 203 & 94.4 \\
\hline & No response & 5 & 2.3 \\
\hline \multirow{4}{*}{$\begin{array}{l}\text { Breast milk stored at room } \\
\text { temperature lasts for }\end{array}$} & 1 hour & 34 & 16.3 \\
\hline & $\underline{8 \text { hours }}$ & 84 & 40.4 \\
\hline & Don't know. & 90 & 43.3 \\
\hline & No response & 12 & 5.5 \\
\hline
\end{tabular}




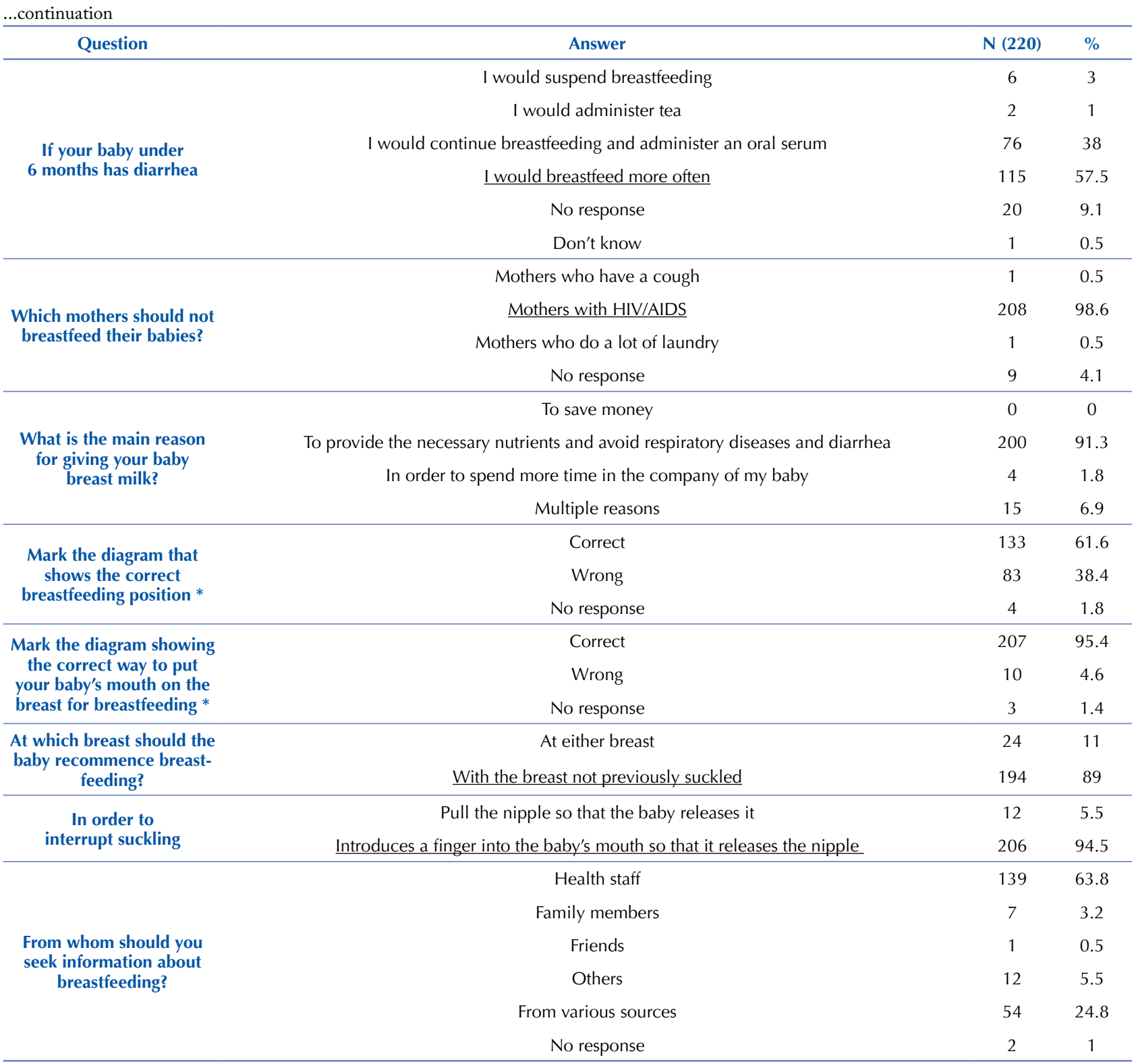

*The correct answers are underlined.

Table 4 - Relationship between the level of basic breastfeeding knowledge and postpartum outcomes - Galicia, Spain, $2014-2015$.

\begin{tabular}{|c|c|c|c|c|c|c|c|}
\hline & & & \multicolumn{4}{|c|}{ Level of BF knowledge } & \multirow{3}{*}{$\mathbf{P}$} \\
\hline & & & \multicolumn{2}{|c|}{ Good/Regular } & \multicolumn{2}{|c|}{ Poor } & \\
\hline & & & $\mathbf{N}$ & $\%$ & $\mathbf{N}$ & $\%$ & \\
\hline \multirow{6}{*}{ Postpartum feeding } & \multirow{2}{*}{$6 w$} & EBF & 110 & 85.3 & 19 & 14.7 & \multirow{2}{*}{0.019} \\
\hline & & AF/mixed F & 51 & 69.9 & 22 & 30.1 & \\
\hline & \multirow{2}{*}{$16 w$} & EBF & 93 & 88.6 & 12 & 11.4 & \multirow{2}{*}{0.003} \\
\hline & & AF/mixed F & 68 & 70.1 & 29 & 29.9 & \\
\hline & \multirow{2}{*}{$6 \mathrm{~m}$} & EBF & 51 & 89.5 & 6 & 10.5 & \multirow{2}{*}{0.05} \\
\hline & & AF/mixed F & 110 & 75.9 & 35 & 24.1 & \\
\hline
\end{tabular}

Note: AF: artificial feeding; EBF: exclusive breastfeeding; Mixed F: mixed breastfeeding; m: months; w: weeks.

\section{DISCUSSION}

The level of BF knowledge in pregnant women in the third trimester of pregnancy was regular, influenced by socio-demographic factors. Nevertheless, this knowledge conditioned the intention, as well as the type of NB feeding.

Socio-demographic factors that relate to the level of BF knowledge are age, number of births and level of studies. 
This fact underlines the importance of ME classes, especially for younger primiparous mothers and those with a lower level of studies, these being the most vulnerable population groups $^{(14-16)}$.

Pregnant women with greater breastfeeding knowledge are those with a more positive disposition in relation to $\mathrm{BF}$, related to intent and postpartum feeding, as may be seen in the results of this study. This discovery not only ratifies the need for pregnancy attention by specialist nurses who, in addition to exclusively clinical aspects ${ }^{(17)}$, should ensure that $\mathrm{ME}$ classes are started earlier, as already mentioned above, because some women decide to breastfeed after attending these classes, where they learned the many advantages of $\mathrm{BF}^{(18)}$.

The following aspects were highlighted in the results of the knowledge questionnaire:

Most participants considered that while away from their baby, they should preferably give them extracted breast milk. However, only $40 \%$ of mothers knew about the storage time of breast milk extracted at room temperature. This highlights the need to advise, especially working mothers, on the conservation of breast milk, with a view to reincorporating them into the working world, so that this does not become a reason for abandoning $\mathrm{BF}$, as it is an argument often used to discontinue breastfeeding prematurely ${ }^{(19-20)}$.

Another important point is that women require information regarding the management of diarrhea. An important percentage of women would take measures without prescription, such as suspending the baby's BF, giving them teas or oral serum, probably due to lack of knowledge of the serious consequences that these actions, at such an early age, may trigger $^{(21)}$.

Regarding the attitude to breastfeeding, 38\% of mothers did not know the correct posture, which coincides with a study conducted in Brazil, in which more than half of the women did not know about correct breast handling or that there is a correct posture for breastfeeding ${ }^{(22)}$. It is necessary to place special emphasis on this aspect in ME classes with an eminently practical approach, in order to prevent problems derived from incorrect positioning of the baby ${ }^{(23)}$.

A point in favor of the effectiveness of classes is the finding that most women recognized that they had obtained information about BM from health personnel. This data places these professionals in a privileged position to provide women with up-to-date information based on scientific evidence. In addition, information obtained from non-health sources (media, social groups, family members, etc.) may not be useful, safe and accurate, and even perpetuate the idea that powdered milk is the norm ${ }^{(24)}$.
The maintenance of exclusive breastfeeding was influenced by the women's level of knowledge. However, this relationship weakens with time, the limit of statistical significance being at 6 months, which shows the importance of monitoring lactating women, especially in the first 3 months postpartum, and not only performing educational interventions in the prenatal phase. This will allow the identification of the difficulties encountered and the performance of interventions that favor the development of maternal safety and satisfactory breastfeeding practice ${ }^{(25-26)}$.

The study presents a limitation inherent to its design. As a prospective observational study, follow-up losses $(n=20)$ were produced in the postpartum stage, and it was not possible to determine the causes of non-responses. The percentage of losses, which was low, does not call into question the results achieved.

On the other hand, the non-recording during the third trimester of pregnancy of the exact time in which women intended to give EBF (6 weeks, 16 weeks or 6 months) did not allow the establishment of an exact comparison with the postpartum results and therefore confirm whether the intention and the results coincide at the three aforesaid moments. However, it was based on the premise that women knew the recommendation to give $\mathrm{EBF}$ up to 6 months due to the information addressed in the ME classes.

Breastfeeding is a refined and personalized practice for both the mother and their baby, so women have the right to know its benefits when they make decisions on how to feed their future baby. Given that BF knowledge conditions the intention and the type of NB feeding, professionals can act in this field to identify women with a low level of knowledge, in order to developing educational strategies to improve $\mathrm{BF}$ rates.

The limitations of the study were related to the loss of follow-up - albeit scarce (8\%) - and the lack of accurate records of the time that women wished to breastfeed.

\section{CONCLUSION}

Most pregnant women had a "regular" level of BF knowledge. This level of knowledge conditions the intention and the type of feeding given to the NB.

Health professionals should identify women with a low level of knowledge and act to improve it, thus increasing BF rates and benefitting maternal and child health.

The fact that the family is an element that influences the decision on how to feed the newborn suggests the need for studies that deepen the attitudes and knowledge of parents and grandmothers about BF, and the effects they have on the mother's decision.

\section{RESUMO}

Objetivo: Determinar o nível de conhecimento sobre aleitamento materno das gestantes e analisar em que medida este influencia a intenção de amamentar após a introdução da alimentação do lactente na $6^{\mathrm{a}}$ e $16^{\mathrm{a}}$ semanas e aos 6 meses pós-parto. Método: Estudo descritivo prospectivo, realizado com gestantes na Galícia (Espanha). Mediante um questionário de autopreenchimento, foram coletados dados sobre a intenção de a mulher alimentar o recém-nascido e os seus conhecimentos sobre o aleitamento materno. Também se contatou as gestantes na $6^{\mathrm{a}}$ e $16^{\mathrm{a}}$ semanas e aos 6 meses pós-parto para conhecer o tipo de alimentação que davam ao seu filho. Resultados: Participaram do estudo 297 gestantes, das quais 90,4\% desejavam alimentar o seu bebê com aleitamento materno exclusivo, no entanto, somente $28,2 \%$ o realizou até os 6 meses. O nível de conhecimento sobre o aleitamento materno foi regular e observou-se que este influencia tanto a intenção como o tipo de alimentação do recém-nascido, é um elemento a ser 
considerado na hora de desenvolver estratégias educativas direcionadas a aumentar as taxas de aleitamento materno. Conclusão: O nível de conhecimento das gestantes sobre aleitamento materno é regular e influencia a escolha da alimentação de seus bebês e a duração do aleitamento materno exclusivo. Devem-se implantar estratégias para aumentar os conhecimentos e melhorar as taxas de aleitamento materno.

\section{DESCRITORES}

Aleitamento Materno; Conhecimento; Gravidez; Enfermagem Materno-Infantil; Educação em Saúde.

\section{RESUMEN}

Objetivo: Determinar el nivel de conocimientos sobre lactancia materna de las gestantes y analizar en qué medida éste influye en la intención de amamantar y en la posterior alimentación del lactante a las 6 y 16 semanas y a los 6 meses posparto. Método: Estudio descriptivo prospectivo, realizado con gestantes en Galicia (España). Mediante un cuestionario autocumplimentado se recogieron datos sobre la intención de la mujer de alimentar al recién nacido y sus conocimientos sobre lactancia materna. Se contactó con las gestantes a las 6 y 16 semanas y a los 6 meses posparto para conocer el tipo de alimentación que daban a su hijo. Resultados: Participaron en el estudio 297 gestantes, de las cuales el 90,4\% deseaba alimentar a su bebé con lactancia materna exclusiva, sin embargo, solo el 28,2\% lo llevó a cabo a los 6 meses. El nivel de conocimientos sobre lactancia materna fue regular y se ha visto que influye tanto en la intención como en el tipo de alimentación del recién nacido por lo que es un elemento a tener en cuenta a la hora de desarrollar estrategias educativas encaminadas a aumentar las tasas de lactancia materna. Conclusión: El nivel de conocimiento de las gestantes sobre lactancia materna es regular e influye en la elección de alimentación de sus bebés y en la duración de la lactancia materna exclusiva. Se deben implantar estrategias para aumentar los conocimientos y mejorar las tasas de lactancia materna.

\section{DESCRIPTORES}

Lactancia Materna; Conocimiento; Embarazo; Enfermería Maternoinfantil; Educación en Salud.

\section{REFERENCES}

1. Victora CG, Bahl R, Barros AJD, França GVA, Horton S, Krasevec J. Breastfeeding in the 21st century: epidemiology, mechanisms, and lifelong effect. Lancet. 2016;387(10017):475-90.

2. Victora CG, Horta BL, Mola CL, Quevedo L, Pinheiro RT, Gigante DP, et al. Association between breastfeeding and intelligence, educational attainment, and income at 30 years of age: a prospective birth cohort study from Brazil. Lancet Glob Health. 2015;3(4):199-205

3. Lamberti LM, Zakarija-Grković I, Walker CLF, Theodoratou E, Nair H, Campbell H, et al. Breastfeeding for reducing the risk of pneumonia morbidity and mortality in children under two: a systematic literature review and metaanalysis. BMC Public Health. 2016;13 Suppl 3:S18.

4. Lamberti LM, Walker CLF, Noiman A, Victora CG, Black RE. Breastfeeding and the risk for diarrhea morbidity and mortality. BMC Public Health. 2011;11 Suppl 3:S15.

5. World Health Organization. Guideline: protecting, promoting and supporting breastfeeding in facilities providing maternity and newborn services [Internet]. Geneva: WHO; 2017 [cited 2018 May 8]. Available from: http://www.who.int/nutrition/publications/guidelines/ breastfeeding-facilities-maternity-newborn/en/

6. Venancio SI, Escuder MML, Saldiva SRDM, Giugliani ERJ. A prática do aleitamento materno nas capitais brasileiras e Distrito Federal: situação atual e avanços. J Pediatr. 2010;86(4):317-24.

7. España. Ministerio de Sanidad y Consumo; Instituto Nacional de Estadística. Estilos de vida [Internet]. Madrid; 2007 [citado 2016 Dec. 12]. Disponible en: http://www.msssi.gob.es/estadEstudios/estadisticas/encuestaNacional/encuestaNac2006/EstilosVidaPorcentaje.pdf

8. Twells LK, Midodzi WK, Ludlow V, Murphy-Goodridge J, Burrage L, Gill N, et al. Assessing infant feeding attitudes of expectant women in a provincial population in Canada: validation of the lowa Infant Feeding Attitude Scale. J Hum Lact. 2016;32(3):NP9-NP18.

9. Rodríguez García R. Aproximación antropológica a la lactancia materna. Rev Antropol Exp. 2015;15(23):407-29.

10. Zielińska MA, Sobczak A, Hamułka J. Breastfeeding knowledge and exclusive breastfeeding of infants in first six months of life. Rocz Panstw Zakl Hig. 2017;68(1):51-59.

11. Wallenborn JT, Ihongbe T, Rozario S, Masho SW. Knowledge of breastfeeding recommendations and breastfeeding duration: a survival analysis on infant feeding practices II. Breastfeed Med. 2017;12:156-62.

12. Ferro Sosa MM, Flores Condory HF. Nivel de conocimiento en lactancia materna y su relación con factores socioculturales en puérperas del IEMP de octubre a diciembre del 2005 [disertación]. Lima: Universidade Nacional Maior de São Marcos; 2006.

13. Cunha CM, Almeida Neto OP, Stackfleth R. Principais métodos de avaliação psicométrica da confiabilidade de instrumentos de medida. Rev Atenção Saúde. 2016;14(49):98-103. DOI: 10.13037/rbcs.vol14n49.3671

14. Mejia CR, Cárdenas MM, Cáceres OJ, García-Moreno KM, Verastegui-Díaz A, Quiñones-Laveriano DM. Actitudes y prácticas sobre lactancia materna en puérperas de un hospital público de Lima, Perú. Rev Chil Obstet Ginecol. 2016;81(4):281-7.

15. Fonseca-Machado MDO, Rezende de Paula MS, Miranda Parreira BD, Stefanello J, Flávia Gomes-Sponholz F. Comparação do conhecimento sobre aleitamento materno entre mulheres no período pós-parto. Rev Enferm UERJ. 2013;21(1):66-72 .

16. Franco-Soto J, Roa-Moreno B, Sánchez L, Socha L, Leal C, Parra K, et al. Conocimiento sobre lactancia materna en embarazadas que acudieron a consulta prenatal. Arch Venez Pueri Pediatr. 2014;77(3):128-32.

17. Sandall J, Soltani H, Gates S, Shennan A, Devane D. Midwife-led continuity models versus other models of care for childbearing women. Cochrane Database Syst Rev. 2016;(4):CD004667.

18. Radzyminski S, Callister LC. Mother's beliefs, attitudes, and decision making related to infant feeding choices. J Perinat Educ. 2016;25(1):18-28. 
19. Balogun OO, Dagvadorj A, Anigo KM, Ota E, Sasaki S. Factors influencing breastfeeding exclusivity during the first 6 months of life in developing countries: a quantitative and qualitative systematic review. Matern Child Nutr. 2015;11(4):433-51

20. Díaz-Gómez NM, Ruzafa-Martínez M, Ares S, Espiga I, De Alba C. Motivaciones y barreras percibidas por las mujeres españolas en relación a la lactancia materna. Rev Esp Saúde Pública. 2016;90: e1-18.

21. Liu L, Oza S, Hogan D, Chu Y, Perin J, Zhu J, et al. Global, regional, and national causes of under-5 mortality in 2000-15: an updated systematic analysis with implications for the Sustainable Development Goals. Lancet. 2016;388(10063):3027-35.

22. Brito A, Caniçali C, Costa MH, Marabotti Costa F. Avaliação do conhecimento de puérperas acerca da amamentação. Enferm Foco. 2015;6(1/4):12-6.

23. Berens PD. Breast pain: engorgement, nipple pain, and mastitis. Clin Obstet Gynecol. 2015;58(4):902-14.

24. Sriraman NK, Kellams A. Breastfeeding: what are the barriers? Why women struggle to achieve their goals. J Womens Health. 2016;25(7):714-22.

25. Skouteri, H, Nagle C, Fowler M, Kent B, Sahota P, Morris H. Interventions designed to promote exclusive breastfeeding in high-income countries: a systematic review. Breastfeed Med. 2014;9(3):113-27.

26. Silva NMD, Waterkemper R, Silva EFD, Cordova FP, Bonilha ALDL. Conhecimento de puérperas sobre amamentação exclusiva. Rev Bras Enferm. 2014;67(2):290-5. 